\title{
Evaluating the Dialogic Potential of Websites of Universities in Ghana
}

\author{
Rhodalene Amartey \\ Final Year Doctoral Student (PhD) \\ Business Administration \\ Accra Institute of Technology
}

\begin{abstract}
The purpose of this paper is to examine the dialogic communications potential of websites of universities in Ghana. The study employed a quantitative content analysis of universities websites in Ghana drawing upon Kent and Taylor's (1998) dialogic communications framework. The results show that many of the websites do not have dialogic principles. Many of the websites do not contain relevant information. Besides, many of the information are dated. The websites do not have features that conserve visitors and many also do not have dialogic loop features. From the findings, the researcher proposes that interaction between websites and users must be considered when websites are being developed
\end{abstract}

Keywords: Ghana, University, Dialogic Communication Theory and Dialogic Principles

\section{Introduction:}

The emergence of the Internet has transformed how organizations communicate with their stakeholders. Communication practices do not evolve as quickly as technology does. This is especially true for educational institutions. The internet therefore offers the potential for educational institutions to share their mission statement and vision to any potential student around the world who may be interested in any of their programmes. However, these educational institutions must be ready to explore the advantages of the interactive sources a website brings to an organization. According to some studies (Waters and Tindall 2010; Kent \& Taylor, 1998), there are specific elements of dialogic communication that organizations can take advantage of to make their websites more useful in cultivating relationships with their target groups. Kent \& Taylor (1998) for example identified the following as elements of a dialogic website: ease of navigation, the provision of usefulness information, the ability to communicate with an organization, the ability to communicate with an organization via the website and the encouragement of future visits to the websites. Once all five criteria are employed, organizations websites are able to spread information and activities of an organization quickly. Waters and Tindall (2010) replicated the earlier rule of Kent and Taylor (1998) by identifying the five criteria - ease of navigation, usefulness of information, the dialogic loop, the generation of return visits, and the rule of conservation of visitors. Studies employing Kent and Taylor's dialogic principles to evaluate websites are in abundance. Many of these studies have focused on corporate organizations' websites with a few focusing on noncorporate institutions websites. De Oliveria and Huertas (2015) for example studied dialogic communication in Brazilian websites from a longitudinal perspective. The objective of the study was to analyze the use of dialogic tools on Brazilian websites in two periods 2010 and 2011. Similarly, Okoe and Boateng (2016) evaluated the dialogic nature of banks operating in Ghana. They noted that ease of interface, usefulness of information and conservation of visitors' features were principles that featured in all the websites studied. Boateng, Agyemang and Dzandu (2015) on the other hand employed content analysis to assess the universities in Ghana libraries' websites. They noted that there are scanty and dated information on the universities libraries' websites. Again, it was clear that the libraries' websites do not contain information that are of importance to the users of the library. The study called for the need for researchers to study the universities websites themselves to ascertain their dialogical potentials since there is paucity of studies on academic institutions' websites. In response to this call, the study evaluates the presence or otherwise of Kent and Taylor (1998)'s dialogic principles on the websites of Universities operating in Ghana. This study contributes to the extant literature by offering the dialogic state of the websites of non-corporate organization, specifically universities. This study will assist universities to develop interactive websites to enable them communicate and build a mutual relationship with their stakeholders. The rest of the study is divided as follows; Part one captures the theoretical background while part two concentrates on the literature review. Part three contains the conceptual framework used for the study while part four focuses on the methodology. Findings and discussions are presented in part five while conclusions and implications of the study are captured in part six. 


\section{Theoretical Background: Dialogic Communication Theory}

According to Kent and Taylor, (1998) the use of technology should not create a gap between an organization and its stakeholders. Rather, it should embrace personal touch which will result in effective communication. With the help of the internet, an opportunity is provided for organizations to target stakeholders otherwise considered as isolated to be contacted by the World Wide Web if the dialogic communication and dialogic capacity of the web are clearly understood. Kent and Taylor (1998) define dialogic communication as "any negotiated exchange of ideas and opinions".

Based on their definition, it is evident that dialogue should be seen as a two way communication relationship based on two principles. Firstly, in a dialogue, parties must be ready to settle at agreed positions but not necessarily agree. Secondly, dialogue is not based on subjectivity or objectivity but rather open discussions. Since the focus of dialogic communication is on negotiated communication, it means engaging in public dialogue in an ethical manner. There is adequate evidence to indicate that the internet can be used as a tool to disseminate information (Waters and Tindall 2010). Dialogic communication is important in building relationships because it brings about a decision from a managerial approach to a public relationships approach where relationships are sustained and managed. Previous studies have shown how websites can be used to build relationships using a content analysis approach. Scholars such as Madiche and Hinson (2014) used content analysis to examine the dialogic potential of organizations websites. Other scholars who have also used content analysis to conduct studies include Ibrahim (2015) and Ibrahim, Adam and De Heer (2015). The study concluded that universities should avoid copying other websites blindly without considering the specific needs of the users as well as other stakeholders. Observations made by Sommerfeldt et al. (2012) indicate that the dialogic principles developed by Kent and Taylor (1998) provided firms with guidelines as to how their websites can serve as two way communication media. However, many organizations have relied heavily on the dialogic principles to design their websites in order to create a mutual relationship with their clients (Waters and Jamal, 2011).

Kent and Taylor's (1998) seminal work on dialogic communications have received a lot of attention from public relations and marketing scholars.A study conducted by Cha et al (2014) examined the dialogic potential of websites of embassies in Korea. They adopted Kent and Taylor's framework usingconceptual lens. They emphasized on the corporate and blog sites of the embassies of UK, USA, Canada, Australia and Israel which were very active in their blogs. The study did not indicate why it limited itself to corporate websites and blogs of embassies. However, it is clear that other embassies are very active on other platforms. Since organization's choice of social media platform is partly dependent on their target group (Wong 2012) compared to the official name page, the US embassy blog better satisfied the dialogic principles (Soon and Soh, 2014; Capriotti and Kuklinsi, 2012). Findings from the study showed that the US embassy blog served low in "Usefulness of information and high in "Conservation of visitors". On the contrary, its corporate website scored high in usefulness of information and low in conservation of visitors.

According to Madiche and Hinson (2014) most police websites in sub Saharan Africa do not provide useful information to their audience. Besides, they do not have the capacity for conservation of visitors and return visits. It is clear that organizations have failed to engage their clients on the corporate websites. The building blocks of relationships between NGOs and news media were assessed by Ting Lee and HemantDesai (2014). The study observed that organizations that have adopted dialogic principles in their communication build stronger relationships with the media. This buttresses the fact that adopting dialogic principles facilitates strong relationships with clients. Similarly, a not for profit health organization was explored to identify how its uses social media to communicate with its stakeholders. Findings from the study showed that the organization uses both mono-dialogue and dialogic principles. The objective of this study is to critically examine the dialogic nature of university websites as defined by Kent and Taylor (1998) and Waters and Tindall (2010) using content analysis. The contribution of this study is the application of quantitative content analysis to determine the dialogic nature of the university websites in an emerging educational sector.

\section{Literature Review}

The past three decades have seen a phenomenal growth of business into world markets. This can be attributed to the fact that information technology is considered an enabler that provides the catalyst for organisations to interpret their global operations. A key component of information technology is the internet which is increasingly becoming an organisation for consumers as a shopping venue. For instance, as far back as 2007, the Internet World Stats Report indicated that the growth rate of internet usage in a developing country like Ghana was nearly $2000 \%$ between 2000 and 2007. Indeed, as far back as 2001, it was estimated that internet users globally run into billions. The internet therefore provides the opportunity for organisations to market themselves and their products online (OECD Report, 2001). 
Keller (2008) argued that in recent times, there has been a paradigm shift in the area of competition and this together with innovations in computing and telecommunications have broken the traditional barriers to competition in the business world. It stands to reason therefore that firms that operate both brick-and-mortar and online formats are more likely to have a competitive edge compared to firms that offer only a simple alternative. These dramatic changes in business operations and execution of complex online delivery systems are now considered as strategic necessities (Simmons, 2007).

A university website is now a necessary tool for offering improved education in terms of quality teaching interaction and convenience to its primary stakeholders.

Universities and colleges can now deploy digital tools to enhance students' involvement in teaching and learning, and curricular collaborative teaching for courses where they lack the requisite faculty and more importantly brand themselves on online. Digital resources can also serve as a need to enhance students' performance and interpretation into the learning experience.

McAllister-Spooner (2009) posited that universities and colleges can develop and maintain relationships with their respective stakeholders through dialogue. According to Tucciarone (2007) universities, especially from developing economies can do this by using their online platforms to attract potential students as well as providing opportunity for the dissemination of information to exiting students. The rationale is that students evaluate their institutions on the basis of information available on college or university websites. As a result of the intense competition, any educational or institution website's online branding becomes a key factor (Kiang Ng, 2003).

In a developing country like Ghana, the tertiary education sector has undergone massive changes in the last two decades due to liberation of the sector. This has culminated in increased competition as new players enter the industry. Traditionally, the state has used legislation to keep out private participation in tertiary education. With the repeal of the law and subsequent liberation of the sector, individuals and religious organisation have established their own universities and colleges in Ghana.

Ghana's tertiary sector has undergone rapid changes in the last decade. According to the National Accreditation Board (NAB) (www.nab.gov.gh) as at May 2015, there were 73 accredited universities and university colleges in Ghana made up of both public and private universities. The battle for the hearts and minds of high school graduates is therefore very high as they begin their college search. In Ghana, aside newspaper advertisements, potential students use university websites as an important source of information on prospective tertiary institutions. University websites are also used to create relationships among current students and wider stakeholders. According to Abrahamson (2000), evidence exists to show that potential students rank college websites as second only to campus visits in their search for universities and colleges. However, studies on how universities brand themselves online are very scanty. It is against this background that this study seeks to investigate the dialogic potential of universities in Ghana websites.

\section{Conceptual Framework: Dialogic Communication Principles}

Using technology should not create a gap between an organization and its publics (Kent and Taylor, 1998). Rather internet communication can add the "personal touch" which will make PR and communication very effective. The internet is very vital and can serve as one of the few ways to target the isolated publics. Public Relations theory has relied heavily on Grunig and Hunt's four models of public relations namely; press agentry, public information, two way asymmetrical and two way symmetrical communications (Grunig and Hunt, 1984). Grunig and Hunt posit that the most preferable medium is the two way symmetrical because it is a prerequisite for understanding dialogic communication (Kent and Taylor, 1998). Building a relationship between dialogic communication and the two way symmetrical can be perceived both as a process and a product. Dialogue can therefore be considered as a product whilst two way symmetrical can be perceived as a process. Other scholars add to the debate by opining that PR goes beyond monitoring. Instead satisfying publics needs demands dialogue and understanding should be the focus. Kent and Taylor (1998) are of the view that because dialogue is a two way communication it must rest on two principles:

- The parties involved must not necessarily agree but must be willing to get to mutually satisfying positions;

- Secondly, a dialogue implies inter-subjectivity as opposed to objectivity or subjectivity.

Studies conducted into dialogic communications have established that corporate websites have the dialogic principles on their websites and social networking sites (Seltzer and Mitrook, 2007).

In this study, the researcher employed Kent and Taylor (1998)'s five principles of dialogic communication: the ease of interface, usefulness of information, dialogic loop, and generation of return visits and conversation of visitors.

The principles have been succinctly explained as follows:

- Usefulness of Information: This discusses how organizations make important information available to all stakeholders in a logical rational and hierarchical manner. 
- Ease of Use: Organizations should develop websites that users can easily understand and navigate (Kent and Taylor, 2004)

- Conservation of Visitors: For a website to function effectively. It must have features and links that will compel visitors to the site to surf for a considerable time.

- Generation of Return Visits: It maintains that websites should foster long term relationships by providing features that encourage return visits.

- Dialogic Loop: Stakeholders should be allowed to query, interact or offer suggestions to the organization for improvement in its services.

The existence of the first four principles facilitates the websites interactivity whilst the fifth principle which is the dialogic loop contains the actual dialogic feature. Kent and Taylor (1998) therefore sum it up by stating that the web gives organizations the chance to firm up their relationships with the public such that the dialogic loop is embedded in the communication of the organization. In this study, the researcher employed these five principles to evaluate the dialogic nature of the Websites of Universities operating in Ghana.

\section{Research Design \& Sampling Technique}

The study employed a quantitative content analysis approach as the research design. The study analysed all the websites of accredited universities operating in Ghana (see Appendix A). Out of a population of 73 accredited universities, 2 did not have websites at all whilst only 65 universities had their websites functioning. The dialogic communication questionnaire developed by Kent and Taylor (1998) and used by many researchers (Hinson, Madiche and Masud, 2012; Waters and Tindall 2010 was adopted for this study. The questionnaire contained 29 items. Usefulness of information has eight questions items relating to the measurement of dialogic communication principles: ease of use has five questions, the dialogic loop has five questions, website's ability to conserve has eight questions and generation of return visits has four questions. Descriptive statistics was employed as a technique for data analysis. It was used to compare the mean, minimum values, maximum values and standard deviation for each dialogic construct and item. The data was provided in tables which summarized the findings for each principle. Using Kent and Taylor's (1998) schema, with respect to analyzing dialogic features of firm's websites, the university's websites were coded. Replicating Kent and Taylor (1998), this technique though very simple was enough for the analysis

\section{Analysis and Discussions of Results}

Five dialogic principles variables were used in analyzing the contents of the websites of universities in Ghana.

Table 1. Usefulness of Information (8)

\begin{tabular}{lll} 
Response & Frequency & Percent \\
\hline \hline $1 / 8$ & 3 & 4.6 \\
$2 / 8$ & 4 & 6.2 \\
$3 / 8$ & 11 & 16.9 \\
$4 / 8$ & 12 & 18.5 \\
$5 / 8$ & 23 & 35.4 \\
$6 / 8$ & 7 & 10.8 \\
$7 / 8$ & 5 & 7.7 \\
Total & 65 & 100.0 \\
\hline
\end{tabular}

Results from the dialogic principle on the usefulness of information presents the number of valid responses obtained from the eight questions assessed under this principle. From a total of 65 assessed university websites using eight questions it was clear that 23 had 5/8 valid response to the eight questions provided representing $35.4 \%, 12$ had 4 valid responses representing 18.5\%, 11 had 3/8 valid responses representing 16.9\%, 7 had 6/8 of the question items valid responses representing $10.8 \%, 5$ had 7 valid responses $7.7 \%, 4$ had $2 / 8$ valid responses representing $6.2 \%$ and 3 had only $1 / 8$ of the question items valid representing $6.2 \%$ of the responses yielded out of the 8 question items used during assessment. From the tables, it showed that all the 65 university had only 7 items relating to the usefulness of information. The findings show that none of the university websites had $8 / 8$ response to the question items.

The second principle is Ease of Interface Use. This principle clearly indicates that organizations should develop websites that users can easily navigate (Kent and Taylor, 2004). Searching for, retrieving and storing information should be made easy for users. Support features such as a site map, search engines and bookmarks are very crucial for dialogic communication on websites. The websites must be friendly to users as well (Madichie and Hinson, 2014). Websites should be flexible and user friendly. Dialogic websites must have main links, a home page with search engines to make data easy to find. 
Table 2. Ease of Interface Use (5)

\begin{tabular}{lll} 
Responses & Frequency & Percent \\
\hline \hline $0 / 5$ & 4 & 6.2 \\
$1 / 5$ & 2 & 3.1 \\
$2 / 5$ & 7 & 10.8 \\
$3 / 5$ & 16 & 24.6 \\
$4 / 5$ & 24 & 36.9 \\
$5 / 5$ & 12 & 18.5 \\
Total & 65 & 100.0 \\
\hline
\end{tabular}

From Table 2, based on the 5 questions asked pertaining to the ease of use of university websites 24 of the websites had $4 / 5$ valid responses representing 36.9\%, 16 had 3/5 valid responses representing 24.6\%, 12 had 5/5 valid responses representing 18.5\%, 7 had 2/5 representing 10.8\%, 2 had 1 valid response representing $3.1 \%$ and 4 had $0 / 5$ of the question items invalid representing $6.2 \%$. This clearly shows that 61 out of the 65 university websites based on the 5 question items used to assess the ease of use are user friendly.

Table 3. Conservation of Visitors (8)

\begin{tabular}{lll} 
Response & Frequency & Percent \\
\hline \hline $0 / 8$ & 1 & 1.5 \\
$1 / 8$ & 1 & 1.5 \\
$2 / 8$ & 4 & 6.2 \\
$3 / 8$ & 16 & 24.6 \\
$4 / 8$ & 14 & 21.5 \\
$5 / 8$ & 24 & 36.9 \\
$6 / 8$ & 3 & 4.6 \\
$7 / 8$ & 2 & 3.1 \\
Total & 65 & 100.0 \\
\hline
\end{tabular}

The third principle is "Conservation of Visitors". For a web to function effectively, certain features and links must be present to compel visitors to the site to surf for a considerable period (Madichie and Hinson, 2014). It is advisable that the link should not have more than three external web pages. However, the external web pages should provide for visitors information needs. This feature persuades visitors or users to return to websites and makes it difficult for them to leave the websites. The results of this study indicate that 24 had at most 5 of the items sought for representing $36.9 \%$, followed by 16 having 3/8 of the items representing 24.6\%, 14 also had 4 of the items representing $21.5 \%, 4$ of the websites had $2 / 8$ of the items representing $6.2 \%, 3$ had 6 of the items present representing $4.6 \%, 2$ had $7 / 8$ representing $3.1 \%$ whilst 1 had $1 / 1$ of the items and another 1 which had $0 / 8$ of the items both representing $1.5 \%$ respectively.

Table 4. Generation of Return Visits (4)

\begin{tabular}{lll} 
Responses & Frequency & Percent \\
\hline \hline $0 / 4$ & 9 & 13.8 \\
$1 / 4$ & 9 & 13.8 \\
$2 / 4$ & 22 & 33.8 \\
$3 / 4$ & 23 & 35.4 \\
$4 / 4$ & 2 & 3.1 \\
Total & 65 & 100.0 \\
\hline
\end{tabular}

Generation of Return Visits, the fourth principle maintains that websites should generate long term relationships calculating features that would encourage return visits. To a certain extent, this will make it easy for users of website to access information through electronic mail and other social technologies (Water and Tindall, 2010). This feature encourages users to return to the website another time. Areas where many of the websites performed well were those that yielded $2 / 4$ and $3 / 4$ responses were 23 representing $35.4 \%$ and 22 representing $33.8 \%$, 9 had $1 / 4$ response representing $13.8 \%$ and 9 also had 0/4 representing 13.8\%. (See Table 4) 
Table 5. Dialogic Loop (5)

\begin{tabular}{lcc} 
Responses & Frequency & Percent \\
\hline \hline None & 4 & 6.2 \\
One & 8 & 12.3 \\
Two & 12 & 18.5 \\
Three & 26 & 40.0 \\
Four & 13 & 20.0 \\
Five & 2 & 3.1 \\
Total & 65 & 100.0 \\
\hline
\end{tabular}

The final principle "Dialogic Loop" relates to queries from stakeholders, interaction and proposing suggestions. This is the most important of all the features. It advocates for the incorporation of interactivity. Websites should afford users opportunity to comment on pertinent issues. From Table 5, the presentation of results shows that 26 of the websites had 3 valid responses representing 40.0\%, 13 had 4 of the items present representing 20.0\%, 12 had 2 of the items presents representing $18.5 \%, 8$ had 1 valid responses representing $12.3 \%, 4$ had none of the features available representing $6.2 \%$ and only 2 had all five valid responses representing $3.1 \%$. It was noted in this study that, averagely the websites lack the dialogic loop features.

\section{Conclusions and Practical Implications}

The main aim of this study was to evaluate the dialogic status of websites of Universities in Ghana using Kent and Taylor (1998)'s dialogic framework. The results show the poor state of websites of universities in Ghana with regard to their dialogic features. Less than half of the websites evaluated had many of the features of the dialogic principles. For example, in terms of usefulness of information, only 24 of the websites had downloadable news items. The websites scored very low in terms of provision of calendar for important events, and statement of philosophies of the various universities. Similarly, the websites performed poorly in the dialogic loop principle. For instance, few of the websites had features that enable users to send emails via the websites. Furthermore, although some of the websites have sites map that enable users to navigate easily on the websites, a few of them had search engines. This suggests that many of the websites are not easy to use since the search engine feature is important with respect to searching for items on the websites. Having the site maps is not enough for users to navigate and retrieve relevant information from the websites. Also, it was established that only two of the websites evaluated are frequently updated. This means most of the information available on the websites is dated. This has the potential of discouraging users from visiting the websites because they do not find new information on the websites and therefore no need to visit the websites. Last but not least, a few of the websites could boast of conservation of visitor's features. Many of the websites did not have the addresses of the relevant departments of the universities on their homepages, neither did they have their working hours available on the websites. This shows that many of the universities' websites were built not to conserve users of the websites.

Overall, from the results of the study, one can conclude that the application of Kent and Taylor's dialogic principles are minimally applied in the creation of websites of universities operating in Ghana. This implies that the universities are not taking advantage of the websites to build relationships with their stakeholders. The practical implications of the study is that the "conservation of visitors" and the "return visits" features must be critically looked at and incorporated by web developers into websites since these features make the website interactive. Future researchers should compare dialogic features in both private and public to establish which ones have dialogic value.

\section{References}

Abrahamson, T. (2000) 'To Web or Not to Web Is No Longer the Question', Journal of college admission, No. 168, pp.6-11.

Agyemang, F. G., Boateng, H. and Dzandu, M. D. (2015) 'Dialogic communication on universities in Ghana libraries' websites’, The Electronic Library, Vol. 33 No.4, pp. 684-697.

Capriotti, P. and Kuklinski, H. P. (2012) 'Assessing dialogic communication through the Internet in Spanish museums', Public Relations Review, Vol. 38 No. 4, pp. 619-626.

Cha, H., Yeo, S. and Kim, B. (2014) 'Social media's dialogic communication of foreign embassies in Korea and public diplomacy: Based on dialogic communication theory', Advanced Science and Technology Letters, Vol. 63, pp. 175-178. 
de Oliveira, M. J. and Huertas, M. K. Z. (2015) 'Does life satisfaction influence the intention (We-Intention) to use Facebook?' Computers in Human Behavior, Vol. 50, pp. 205-210.

Grunig, J.E. and Hunt, T. (1984) Managing Public Relations, Holt, Rinehart and Winston, Fort Worth, TX.

Hinson, R. Madichie, N. and Masud, I. (2012) 'A dialogue communications interrogation of the online brand depositions of banks operating in Ghana', International Journal of Bank Marketing, Vol. 30 No. 7.

Ibrahim, A. B. (2015) 'Strategy types and small firms' performance an empirical investigation', Journal of Small Business Strategy, Vol. 4 No. 1, pp. 13-22.

Ibrahim, M., Adam, D. R. and De Heer, F. (2015) 'Interrogation of dialogic potential of university websites in Ghana', Information Development, Vol. 31 No. 2, pp. 123-134.

Kent, M.L. and Taylor, M. (1998) 'Building dialogic relationships through the world wide web', Public Relations Review, Vol. 24 No. 3, pp. 321-334.

Kent, M. L., and Taylor, M. (2004) 'Congressional web sites and their potential for public dialogue. Atlantic Journal of Communication, Vol. 12 No. 2, pp. 59-76.

Keller, K.L. (2008) Strategic brand management: Building, measuring and managing brand equity, $3^{\text {rd }}$ ed., Pearson Education Prentice-Hall,

Kiang, N. Y. (2003) 'A discourse analysis of e-mail messages in a Malaysian business community', GEMA Online® Journal of Language Studies, Vol. 3 No.1.

Madichie, N. O., and Hinson, R. (2014) 'A critical analysis of the "dialogic communications" potential of sub-Saharan African Police Service websites', Public Relations Review, Vol. 40 No. 2, pp. 338-350.

McAllister-Spooner S.M (2009) 'Fulfilling the dialogic promise: A ten year reflective survey on dialogic internet principles', Public Relations Review, Vol. 35, pp. 320-322.

OECD (2001) Citizens as partners, information consultation and participation in policy-making, Organization for Economic Co-operation and Development Report, Paris

Okoe, A. F. and Boateng, H. (2016) 'Two-way communication on bank websites in Ghana: A data triangulation approach', Information Development, Vol. 32 No. 5, pp. 1471-1484.

Seltzer, T. and Mitrook, M. A. (2007) 'The dialogic potential of weblogs in relationship building', Public Relations Review, Vol. 33 No. 2, pp. 227-229.

Simmons, G.J (2007) 'I-branding: Developing the internet as a branding tool', Marketing intelligence and planning, Vol. 25 No. 6, pp. 544-562

Sommerfeldt, E. J., Kent, M. L. and Taylor, M. (2012) 'Activist practitioner perspectives of website public relations: Why aren’t activist websites fulfilling the dialogic promise?' Public Relations Review, Vol. 38 No. 2, pp. 303312.

Soon, C., and Soh, Y. D. (2014) 'Engagement@ Web 2.0 between the government and citizens in Singapore: Dialogic communication on Facebook?’ Asian Journal of Communication, Vol. 24 No. 1, pp. 42-59.

Ting Lee, S. and Hemant Desai, M. (2014) 'Dialogic communication and media relations in non-governmental organizations', Journal of Communication Management, Vol. 18 No. 1, pp.80-100.

Tucciarone, K. M. (2007) 'Cinematic college: national lampoon's animal house teaches theories of student development', College Student Journal, Vol. 41(4), 843-859.

Wong, T. (2012) The Straits Times, Saturday special report: Audience reach; MPs going cyber, D1-D7.

Waters, R.D. and Tindall, T. J (2010) 'Marketing churches on the internet: An analysis of the dialogic potential of Christian websites',International journal of nonprofit and voluntary sector marketing. Vol. 15, pp.369-381

Waters, R.D. and Jamal (2011) 'Tweet, tweet, tweet': A content analysis of non-profit organizations twitter updates', Public Relations Review, Vol. 37, pp. 321-324

\section{APPENDIX A}

\section{University Names and Website Links}

1. Accra Institute of Technology - www.ait.edu.gh

2. Advance Business College - www.advancebusinesscollege.com

3. African University College of Communications - www.aucc.edu.gh

4. Akim State College - www.asuc.edu.gh

5. All Nations University College - www.anuc.edu.gh

6. Almond University - www.almond.edu.gh

7. Anglican University College of Technology - www.angutech.edu.gh

8. Ashesi University - www.ashesi.edu.gh

9. Baldwin University - www.baldwin.edu.gh

10. Blue Crest University - www.bluecrest.edu.gh

11. Catholic Institute of Business and Technology - www.cibtghana.net 
12. Catholic University College of Ghana - www.cug.edu.gh

13. Central University - www.central.edu.gh

14. China Europe International Business School, Ghana - www.ceibs.edu

15. Christ Apostolic University College - www.cauc.edu.gh

16. Christian Service University College - www.csuc.edu.gh

17. International Community College - www.icc.edu.gh

18. Data Link Institute - www.datalink.edu.gh

19. Dominion University College - www.duc.edu.gh

20. Ensign University College - www.ensign.edu.gh

21. Entrepreneurship Training Institute - www.eti.com.gh

22. Evangelical Presbyterian University College - www.epuc.edu.gh

23. Fountain Head Christian University College - www.fcuc.edu.gh

24. Garden City University College - www.gcuc.edu.gh

25. Ghana Baptist University College - www.gbuc.edu.gh

26. Ghana Christian University College - www.ghanacu.org

27. Ghana Institute of Journalism - www.gij.edu.gh

28. Ghana Technology University College - www.gtuc.edu.gh

29. Good News Theological College \& Seminary - www.gntes.org

30. Heritage Christian College - www.hcu.edu.gh

31. Institute of Development and Technology Management - www.idtmdev.org

32. Islamic University Ghana - www.iug.edu.gh

33. Jayee University College - www.juc.edu.gh

34. Joyce Ababio College of Creative Design - www.jaccd.edu.gh

35. Kaaf University College - www.kaafuniversitycollege.edu.gh

36. Kessben University College - www.kc.edu.gh

37. Kings University College - www.kuc.edu.gh

38. Knustford University - www.knustford.edu.gh

39. Lancaster University - www.lancaster.edu.gh

40. Maranatha University College - www.muc.edu.org

41. Marshalls University College - www.marshalls.edu.gh

42. Methodist University College Ghana - www.mucg.edu.gh

43. Millar Institute - www.millarinstitute.com

44. Mount Crest University - www.mountcrestuniversity.edu.gh

45. Nobel International Business School - www.nibs.edu.gh

46. Pan African University College - www.pacuc.edu.gh

47. Pentecost University College - www.pentvars.edu.gh

48. Presbyterian University College - www.presbyuniversity.edu.gh

49. Radford University College - www.radforduc.edu.gh

50. Regent University College - www.regent.edu.gh

51. Spiritan University College - www.spiritanuc.edu.gh

52. St. Nicholas Seminary

53. St. Margaret University College - www.smuc.edu.gh

54. Takoradi Technical University - www.ttu.edu.gh

55. University College of Management Studies - www.ucoms.edu.gh

56. Webster University - www.webster.edu/gh

57. West End University College, Ghana - www.weuc.edu.gh

58. Wisconsin International University College, Ghana - www.wiuc-ghana.edu.gh

59. Yeshua Institute of Technology - www.yeshuaghana.net

60. Zenith College, Ghana www.zenithcollegeghana.org

61. Kofi Annan International Peacekeeping Training Centre - www.kaiptc.org

62. Akrofi-Christaller Institute - www.acighana.org

63. NarhBita College - www.narhbita.com.gh

64. Ghana Institute of Management and Public Administration - www.gimpa.edu.gh

65. Kwame Nkrumah University of Science and Technology - www.knust.edu.gh

66. University of Education, Winneba - www.uew.edu.gh

67. University of Development Studies - www.uds.edu.gh

68. University of Cape Coast - www.ucc.edu.gh

69. University of Energy and Natural Resources - www.uenr.edu.gh

70. University of Ghana - www.ug.edu.gh

71. University of Health and Allied Sciences - www.uhas.edu.gh

72. University of Mines and Technology - www.umat.edu.gh

73. University of Professional Studies Accra - www.upsa.edu.gh 